\title{
Properties of lightweight dry masonry mixtures for winter conditions
}

\author{
Vyacheslav Semenov ${ }^{1, *}$ \\ ${ }^{1}$ Moscow State University of Civil Engineering, 129337, 26, Yaroslavskoye Shosse, Moscow, Russia
}

\begin{abstract}
The construction of building envelopes using effective smallpiece elements requires the use of lightweight masonry mortars, obtained, as a rule, from dry mixtures. One of the most effective ways to obtain such mortars is the introduction of hollow ceramic microspheres into their composition as a lightweight filler. For the climatic conditions of the Russian Federation, it is relevant to use dry masonry mixtures in the winter version, which gain strength at negative temperatures. The main purpose of this work was the development of optimal compositions of modified dry masonry mixes with hollow ceramic microspheres and antifreeze additives for use in winter conditions. Determination of the main properties of dry mixes and masonry mortars was carried out according to standard methods. $\mathrm{X}$-ray diffraction and scanning electron microscopy were used to research of the microstructure and phase composition of the materials. As a result of this research, the compositions of the lightweight dry masonry mixtures for winter conditions were developed. The main properties of the mortar mixtures and mortars were determined and structure and composition of new phases of cement stone were studied as well.
\end{abstract}

\section{Introduction}

Currently housing construction, including low-rise construction, is one of the priorities of the construction industry, secured by a series of national projects and programs. The most applicable wall systems include multilayer systems using small-piece elements - blocks of cellular concrete, lightweight concrete with porous aggregates, effective ceramic elements, etc. These systems can be created with or without an additional layer of effective thermal insulation. As known, to ensure the thermal homogeneity of such structures, lightweight masonry mortars (dry mixes) are used, whose properties - medium density, thermal conductivity, strength should be in accordance with the basic material of the wall (Table 1) [1-2].

As can be seen from Table 1, for use in conjunction with ceramic materials, it is necessary to ensure an average density of the mortar at the level of $800 \ldots 1200 \mathrm{~kg} / \mathrm{m}^{3}$, compressive strength $-5.0 \ldots 15.0 \mathrm{MPa}$, coefficient of thermal conductivity $-0.18 \ldots 0.24$ $\mathrm{W} /\left(\mathrm{m} \cdot{ }^{\circ} \mathrm{C}\right)$, frost resistance - not lower than 50 cycles; and for use with lightweight concretes, the average density of the mortar in dry state should be $500 \ldots 600 \mathrm{~kg} / \mathrm{m}^{3}$,

* Corresponding author: science-isa@yandex.ru 
compressive strength - not lower than 5.0 $\mathrm{MPa}$, coefficient thermal conductivity $0.1 \ldots 0.18 \mathrm{~W} /\left(\mathrm{m}^{\circ} \mathrm{C}\right)$, the frost resistance - not lower than 50 cycles.

Table 1. The main properties of some modern structural thermal insulating piece wall materials.

\begin{tabular}{|c|c|c|c|c|}
\hline Name of material & $\begin{array}{c}\text { Average material } \\
\text { density } \rho_{\mathrm{m}}, \mathrm{kg} / \mathrm{m}^{3}\end{array}$ & $\begin{array}{c}\text { Compressive } \\
\text { strength, } \mathrm{MPa}\end{array}$ & $\begin{array}{c}\text { Coefficient of thermal } \\
\text { conductivity (in dry } \\
\text { state) } \lambda_{\text {dry }}, \mathrm{W} /\left(\mathrm{m} \cdot{ }^{\circ} \mathrm{C}\right)\end{array}$ & $\begin{array}{c}\text { Frost } \\
\text { resistance } \\
\text { grade }\end{array}$ \\
\hline Ceramic stone & $800 \ldots 1200$ & $2,5 \ldots 15$ & $0,18 \ldots 0,24$ & $25 \ldots 50$ \\
\hline $\begin{array}{c}\text { Aerated concrete } \\
\text { blocks }\end{array}$ & $500 \ldots 600$ & $2,5 \ldots 5$ & $0,12 \ldots 0,14$ & $25 \ldots 100$ \\
\hline $\begin{array}{c}\text { Polystyrene } \\
\text { concrete blocks }\end{array}$ & $500 \ldots 600$ & $1,5 \ldots 2,5$ & $0,1 \ldots 0,2$ & $25 \ldots 75$ \\
\hline $\begin{array}{c}\text { Wood-concrete } \\
\text { blocks }\end{array}$ & $500 \ldots 600$ & $0,75 \ldots 2,5$ & $0,1 \ldots 0,18$ & $25 \ldots 50$ \\
\hline
\end{tabular}

The climate of the Russian Federation is characterized by a long period of negative temperatures. In some areas of the country, the winter period reaches 10 months, which necessitates the conduct of construction works (including masonry) at negative temperatures.

Analysis of lightweight dry masonry mixtures for winter works available on the market showed that the compressive strength of mortars usually doesn't exceed 5.0 MPa, the average density isn't less than $700 \mathrm{~kg} / \mathrm{m}^{3}$, the temperature range of the mixes use is $-10 \ldots+5^{\circ} \mathrm{C}$. Mortar is guaranteed to gain only $30 \%$ strength at negative temperatures after 28 days of hardening. In fact, the mortars may not gain the minimum compressive strength of $1.0 \mathrm{MPa}$, as regulated by normative documents [3]. In addition, mortars with antifreeze additives can produce salt efflorescence on the surface of the masonry.

The article deals with the actual problem of developing efficient lightweight dry masonry mixtures for working in winter conditions.

\section{Problem statement}

In order to achieve the aforesaid characteristics of masonry mortars is possible only with the use of lightweight aggregates, which are traditionally used as expanded perlite sand and vermiculite sands, expanded polystyrene granules and foam glass, etc. Such mortars are characterized by high water demand, low compressive strength (usually in the range of 1.0...2.5 MPa, but not higher than 5.0 MPa), low frost resistance $(<35$ cycles) $[2,4]$.

A series of works have shown the high efficiency of use as lightweight aggregates for cement systems [5-10], including building mortars and dry building mixtures of hollow microspheres - glass and aluminosilicate. The spherical shape of the aggregate provides greater plastic properties of the mixes and higher compressive strength. The use of microspheres in the compositions of dry masonry mixes for masonry works allows to obtain an effective composite material with high strength and thermal characteristics [1114]. The use of aluminosilicate (ceramic) microspheres is preferable because they are cheaper than glass and are industrial waste [2].

The author has researched in his works [15-16] the properties, composition and structure of lightweight dry masonry mixes with hollow ceramic microspheres. A rational composition of the dry mix was obtained, containing $60 \%$ of hollow ceramic microspheres of binder mass, modified with superplasticizer at the dosage of $0.4 \%$, air entraining additive at the dosage of $0.02 \%$, and redispersible polymer powder at $3 \%$ of binder mass. The optimal consumption of microspheres is determined as a result of computer modelling of the composite structure, taking into account the known granulometric composition of the aggregate and the binder [17]. The optimal consumptions of modifiers are determined as a 
result of experimental researches [15]. The specified composition in this research is taken as a control and its main properties are given in Tables 2-4. The developed composition significantly exceeds analogues in all characteristics.

The simplest way to ensure the conditions for the process of hydration of the binder at negative temperatures is to use the antifreeze additives, which is realized in particular in the compositions of dry mixes for masonry work. The processes of hydration of Portland cement in the presence of antifreeze additives are significantly complicated by the interaction of additives with clinker minerals and their hydration products. When the water temperature decreases, the polymer components of the dry mixture also cease to function.

The purpose of this work was the development of optimal compositions of modified dry masonry mixes with hollow ceramic microspheres and antifreeze additives for use in winter conditions, as well as the study of their basic properties, structure and composition of new growths of cement stone.

\section{Materials and methods}

To obtain a lightweight masonry mortar the following materials were used. Portland cement CEM I 42.5 N was used as a binder. Hollow ceramic thin-walled microspheres (HCMS) with a fraction of $1 . . .500 \mu \mathrm{m}$ (INOTEK, Siberia Kuznetsky) were used as a lightweight aggregate. The average particle size was $300 \mu \mathrm{m}$, the microsphere wall thickness was equal to $0.1 \ldots 10 \mu \mathrm{m}$. The bulk density of the microspheres was $370 \ldots 390 \mathrm{~kg} / \mathrm{m}^{3}$, the strength under hydrostatic compression (10\% failure) was $15 \ldots .28 \mathrm{MPa}$, the thermal conductivity coefficient of the microspheres was $0.08 \mathrm{~W} /\left(\mathrm{m} \cdot{ }^{\circ} \mathrm{C}\right)$ at $20^{\circ} \mathrm{C}$. A superplasticizer PERAMIN SMF 10, an air-entraining additive (AEA) ASCO 93 and a redispersible polymer powder (RPP) Vinnapas 8034 were used as the modifiers of masonry mortar structure. The following antifreeze additives (AFA) were used: potassium carbonate $\left(\mathrm{K}_{2} \mathrm{CO}_{3}\right)$, sodium formate $(\mathrm{HCOONa})$, sodium nitrite + sodium sulfate $\left(\mathrm{NaNO}_{2}+\mathrm{Na}_{2} \mathrm{SO}_{4}\right)$. Powder-repellent based on organosiloxanes Sitren P 730 was used as a water-repellent additive to reduce the probability of salt efflorescence formation. Wine acid was used to slow down the setting of mortar mixes with $\mathrm{K}_{2} \mathrm{CO}_{3}$.

Determination of the main properties of dry mixes and masonry mortars was carried out according to standard methods (GOST). Microstructural analysis of lightweight masonry mortar samples was carried out using an FEI Quanta 200 scanning electron microscope. Phase analysis of lightweight masonry mortar samples was performed on an ARL X'tra diffractometer.

\section{Results}

Earlier, the authors of [3] researched the properties of lightweight dry building mixtures with hollow ceramic microspheres and various antifreeze additives - lithium carbonate $\left(\mathrm{Li}_{2} \mathrm{CO}_{3}\right)$, potassium carbonate $\left(\mathrm{K}_{2} \mathrm{CO}_{3}\right)$, trisodium phosphate $\left(\mathrm{Na}_{3} \mathrm{PO}_{4}\right)$, sodium formate $(\mathrm{HCOONa})$, sodium nitrite + sodium sulfate $\left(\mathrm{NaNO}_{2}+\mathrm{Na}_{2} \mathrm{SO}_{4}\right)$, sodium thiosulfate + sodium thiocyanate + sodium sulfate $\left(\mathrm{Na}_{2} \mathrm{~S}_{2} \mathrm{O}_{3}+\mathrm{NaSCN}+\mathrm{Na}_{2} \mathrm{SO}_{4}\right)$. The consumption of antifreeze additives was determined according to the method [3] in a calculated manner, depending on the water-cement ratio of mortar mixes. The technological properties of mortar mixes and the physical-and-mechanical properties of modified dry mixes with hollow ceramic microspheres and various antifreeze additives in the hardened state were also researched - tensile strength under bending and compressive strength after 14 and 28 days at hardening temperatures of $(20 \pm 2)^{\circ} \mathrm{C}$ and $-10^{\circ} \mathrm{C}$. 
It was fond out that the most effective antifreeze additive for lightweight dry masonry mixes with HCMS, AEA and RPP is potassium carbonate. However, in case if it is unacceptable to increase the average density of the mortar, it is advisable to use the sodium formate or the complex "sodium nitrite + sodium sulfate" as antifreeze additive. It is preferable to use an additive of sodium formate due to the toxicity of sodium nitrite. So, it has been established that the introduction of sodium formate, sodium nitrite + sodium sulphate complex or potash with a retarder into the dry mixture with hollow ceramic microspheres allows to obtain a mortar with low average density and sufficient strength that can be effectively used during masonry works in winter. The results are given in Table 2. These compositions can be considered as the most rational and further researches were carried in relation to them.

Table 2. The composition and properties of a modified light-weight mortar with HCMS and AFA.

\begin{tabular}{|c|c|c|c|c|c|c|c|c|c|c|c|}
\hline \multirow{3}{*}{$\begin{array}{l}\text { Composition, } \\
\text { mass } \%\end{array}$} & \multirow{3}{*}{$\begin{array}{c}\text { Average } \\
\text { mortar } \\
\text { density } \\
\rho_{\mathrm{m}}, \mathrm{kg} / \mathrm{m}^{3}\end{array}$} & \multirow{3}{*}{$\begin{array}{c}\text { Water } \\
\text { retention, } \\
\%\end{array}$} & \multirow{3}{*}{$\begin{array}{c}\text { Storabilit } \\
\text { y of } \\
\text { initial } \\
\text { mobility }\end{array}$} & \multicolumn{4}{|c|}{ Compressive strength, $\mathrm{MPa}$} & \multicolumn{4}{|c|}{$\begin{array}{c}\text { Tensile bending strength, } \\
\mathrm{MPa}\end{array}$} \\
\hline & & & & \multicolumn{2}{|c|}{$\mathrm{t}=(20 \pm 2){ }^{\circ} \mathrm{C}$} & \multicolumn{2}{|c|}{$\mathrm{t}=-10^{\circ} \mathrm{C}$} & \multicolumn{2}{|c|}{$\mathrm{t}=(20 \pm 2)$} & \multicolumn{2}{|c|}{$\mathrm{t}=-10^{\circ} \mathrm{C}$} \\
\hline & & & & $\begin{array}{c}14 \\
\text { days }\end{array}$ & $\begin{array}{c}28 \\
\text { days }\end{array}$ & $\begin{array}{c}14 \\
\text { days }\end{array}$ & $\begin{array}{c}28 \\
\text { days }\end{array}$ & $\begin{array}{c}14 \\
\text { days }\end{array}$ & $\begin{array}{c}28 \\
\text { days }\end{array}$ & $\begin{array}{c}14 \\
\text { days }\end{array}$ & $\begin{array}{c}28 \\
\text { days }\end{array}$ \\
\hline $\begin{array}{l}\text { Reference } \\
\text { composition } \\
\text { (RC) }\end{array}$ & 831 & 93.5 & $\begin{array}{l}4 \mathrm{~h} 50 \\
\min \end{array}$ & 7.03 & 8.38 & - & - & 1.56 & 1.89 & - & - \\
\hline $\mathrm{RC}+5 \% \mathrm{SF}$ & 883 & 93 & $\begin{array}{l}4 \mathrm{~h} 40 \\
\min \end{array}$ & 8.16 & 10.30 & 3.44 & 4.34 & 1.61 & 2.56 & 1.58 & 1.99 \\
\hline \begin{tabular}{|l|}
$\mathrm{RC}+5 \% \mathrm{SF}+$ \\
$0.3 \% \mathrm{WR}$
\end{tabular} & 858 & 94 & $\begin{array}{c}4 \mathrm{~h} 50 \\
\min \end{array}$ & 7.98 & 10.07 & 2.51 & 3.16 & 1.64 & 2.60 & 1.63 & 2.06 \\
\hline \begin{tabular}{|l|}
$\mathrm{RC}+4.5 \% \mathrm{SN}$ \\
$+1.5 \% \mathrm{SS}$ \\
\end{tabular} & 869 & 94 & $\begin{array}{c}5 \mathrm{~h} 20 \\
\min \end{array}$ & 9.22 & 11.64 & 3.36 & 4.14 & 1.62 & 2.57 & 1.75 & 2.21 \\
\hline $\begin{array}{l}\mathrm{RC}+4.5 \% \mathrm{SN} \\
+1.5 \% \mathrm{SS}+ \\
0.3 \% \mathrm{WR}\end{array}$ & 890 & 94 & $\begin{array}{l}5 \mathrm{~h} 30 \\
\min \end{array}$ & 8.02 & 10.13 & 2.85 & 3.60 & 1.78 & 2.77 & 1.58 & 2.01 \\
\hline \begin{tabular}{|l|}
$\mathrm{RC}+7 \% \mathrm{P}+$ \\
$0.3 \% \mathrm{R}$
\end{tabular} & 957 & 95 & $\begin{array}{l}4 \mathrm{~h} 00 \\
\min \end{array}$ & 14.68 & 18.54 & 5.53 & 6.98 & 2.49 & 3.67 & 2.26 & 2.85 \\
\hline \begin{tabular}{|l|}
$\mathrm{RC}+7 \% \mathrm{P}+$ \\
$0.3 \% \mathrm{R}+0.3 \%$ \\
$\mathrm{WR}$
\end{tabular} & 918 & 95 & $\begin{array}{l}4 \mathrm{~h} 00 \\
\min \end{array}$ & 14.16 & 17.88 & 5.86 & 7.39 & 2.65 & 3.87 & 2.36 & 2.98 \\
\hline
\end{tabular}

SF - sodium formate, SN - sodium nitrite, SS - sodium sulphate, R - retarder (wine acid); WR water repellent. The AFA flow is given in mass \% of the binder mass.

The introduction of antifreeze additives into the dry building mixes with hollow ceramic microspheres, air-entraining additive and redispersible polymer powders has a significant impact on their hydrophysical properties. The results of the determination of the water absorption of the mortar with full immersion and with capillary absorption are shown in Table. 3

Table 3 shows that the addition of sodium formate and complex "sodium nitrite + sodium sulphate" into the dry mixture leads to an increase in water absorption of the mortar by $17 \%$ by mass and by $27 \%$ by volume for sodium formate and by $24 \%$ by mass and $32 \%$ by volume for the complex "sodium nitrite + sodium sulfate" The addition of potash with the retarder reduces the water absorption of the mortar by mass by $15 \%$, but due to the increased average density it increases the water absorption by volume by $9 \%$. All compositions with the addition of water-repellent agent showed a significant decrease in water absorption. 
Test results of masonry mortar for water resistance and frost resistance are given in Table 4. Analysis of the information presented in the Table 4 shows that the introduction of antifreeze additives reduces the water resistance of mortars compared with the reference composition, this is especially clearly for mortars with additives of sodium formate and the complex "sodium nitrite + sodium sulfate".

Table 3. Water absorption of the mortar obtained from lightweight dry masonry mix with HCMS, AEA, RPP and AFA.

\begin{tabular}{|c|c|c|c|c|c|c|}
\hline \multirow{2}{*}{ № } & \multirow{2}{*}{ Composition, mass $\%$} & \multirow{2}{*}{$\mathrm{W} / \mathrm{C}$} & \multirow{2}{*}{$\begin{array}{l}\text { The average } \\
\text { density of the } \\
\text { mortar (in dry } \\
\text { state), } \mathrm{kg} / \mathrm{m}^{3}\end{array}$} & \multicolumn{2}{|c|}{$\begin{array}{c}\text { Water absorption, } \\
\%\end{array}$} & \multirow{2}{*}{$\begin{array}{c}\text { Capillary water } \\
\text { absorption, } \\
\mathrm{kg} /\left(\mathrm{m}^{2} \cdot \mathrm{h}^{0,5}\right)\end{array}$} \\
\hline & & & & $\begin{array}{c}\text { By } \\
\text { mass }\end{array}$ & $\begin{array}{c}\text { By } \\
\text { volume }\end{array}$ & \\
\hline 1 & $\begin{array}{c}\text { Reference } \\
\text { composition (CC) }\end{array}$ & 0,65 & 598 & 9,2 & 5,6 & 0,3 \\
\hline 2 & $\mathrm{RC}+5 \% \mathrm{SF}$ & 0,63 & 659 & 10,8 & 7,12 & 0,3 \\
\hline 3 & $\begin{array}{c}\mathrm{RC}+5 \% \mathrm{SF}+0,3 \% \\
W R\end{array}$ & 0,62 & 638 & 5,2 & 3,32 & 0,2 \\
\hline 4 & $\begin{array}{c}\mathrm{RC}+4,5 \% \mathrm{SN}+ \\
1,5 \% \mathrm{SS}\end{array}$ & 0,6 & 648 & 11,4 & 7,38 & 0,3 \\
\hline 5 & $\begin{array}{c}\mathrm{RC}+4,5 \% \mathrm{SN}+ \\
1,5 \% \mathrm{SS}+0,3 \% \mathrm{WR}\end{array}$ & 0,61 & 668 & 5,8 & 3,87 & 0,2 \\
\hline 6 & $\mathrm{RC}+7 \% \mathrm{P}+0,3 \% \mathrm{R}$ & 0,53 & 781 & 7,8 & 6,09 & 0,2 \\
\hline 7 & $\begin{array}{c}\mathrm{RC}+7 \% \mathrm{P}+0,3 \% \mathrm{R} \\
+0,3 \% \mathrm{WR}\end{array}$ & 0,56 & 724 & 4,1 & 2,97 & 0,1 \\
\hline
\end{tabular}

The addition of a water repellent can improve the water resistance of mortars. The water resistance coefficient of mortars with antifreeze additives and water-repellent agent is $0.83 \ldots 0.92$.

Table 4. Water resistance and frost-resistance of the mortar obtained from lightweight dry masonry mixture with HCMS, AEA, RPP and AFA.

\begin{tabular}{|c|c|c|c|c|c|}
\hline № & Composition, mass \% & W/C & $\begin{array}{c}\text { The average } \\
\text { density of the } \\
\text { mortar (in dry } \\
\text { state), kg/m }\end{array}$ & $\begin{array}{c}\text { Water } \\
\text { resistance } \\
\text { coefficient }\end{array}$ & $\begin{array}{c}\text { Frost resistance } \\
\text { degree, cycles }\end{array}$ \\
\hline 1 & $\begin{array}{c}\text { Reference composition } \\
\text { (CC) }\end{array}$ & 0,65 & 598 & 0,89 & 75 \\
\hline 2 & $\mathrm{RC}+5 \% \mathrm{SF}$ & 0,63 & 659 & 0,83 & 50 \\
\hline 3 & $\mathrm{RC}+5 \% \mathrm{SF}+0,3 \% \mathrm{WR}$ & 0,62 & 638 & 0,90 & 75 \\
\hline 4 & $\begin{array}{c}\mathrm{RC}+4,5 \% \mathrm{SN}+1,5 \% \\
\mathrm{SS}\end{array}$ & 0,6 & 648 & 0,81 & 50 \\
\hline 5 & $\begin{array}{c}\mathrm{RC}+4,5 \% \mathrm{SN}+1,5 \% \\
\mathrm{SS}+0,3 \% \mathrm{WR}\end{array}$ & 0,61 & 668 & 0,83 & 75 \\
\hline 6 & $\mathrm{RC}+7 \% \mathrm{P}+0,3 \% \mathrm{R}$ & 0,53 & 781 & 0,87 & 75 \\
\hline 7 & $\mathrm{RC}+7 \% \mathrm{P}+0,3 \% \mathrm{R}+$ & 0,56 & 724 & 0,92 & 100 \\
\hline
\end{tabular}

The information from table 4 shows that the frost resistance degree of mortars with additives of sodium formate and the complex "sodium nitrite + sodium sulfate" is reduced by one step compared with the control composition, and the frost resistance degree of mortar with potassium carbonate and retarder setting corresponds to the reference composition. The introduction of the water-repellent agent into the composition allowed to 
increase the frost resistance degree of mortars of every composition by 1 step, while the frost resistance degree of the composition with potassium carbonate, retarder and water repellent exceeded the same indicator for the reference composition and was equal to 100 cycles.

The microstructure of the samples of the mortars with antifreeze additives were investigated by the method of scanning electron microscopy. Figures 1 and 2 show the microstructure of a lightweight masonry mortar with hollow ceramic microspheres, airentraining additive, redispersible polymer powder and different antifreeze additives.

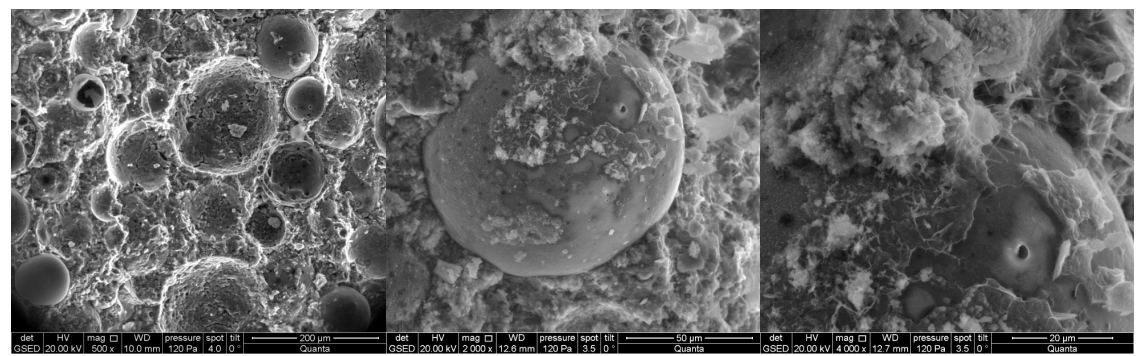

Fig. 1. Microstructure of a lightweight masonry mortar with hollow ceramic microspheres, airentraining additive, redispersible polymer powder, sodium formate and water repellent.

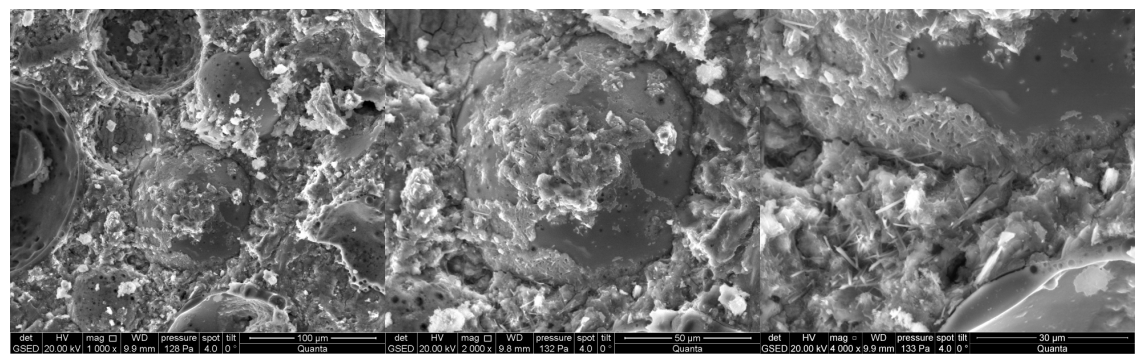

Fig. 2. Microstructure of a lightweight masonry mortar with hollow ceramic microspheres, airentraining additive, redispersible polymer powder, potassium carbonate and water repellent.

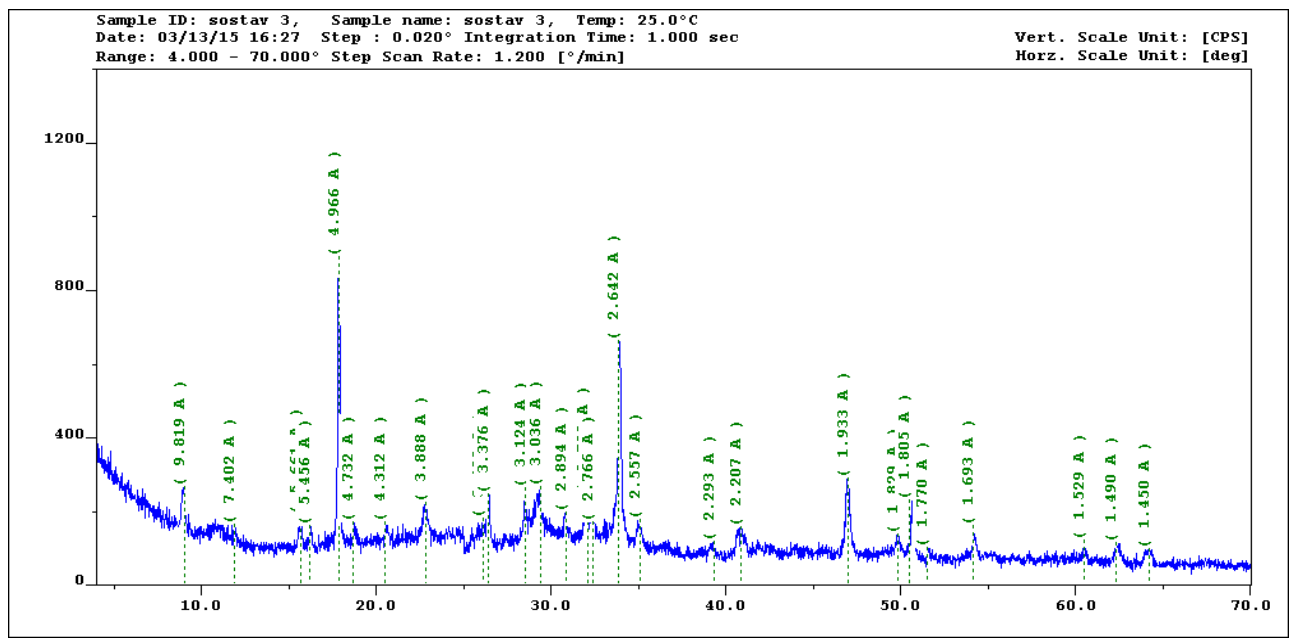

Fig. 3. X-ray diagram of a lightweight masonry mortar with hollow ceramic microspheres, airentraining additive, redispersible polymer powder, complex "sodium nitrite + sodium sulfate" and water repellent. 
The microstructure is represented mainly by hollow ceramic microspheres uniformly distributed throughout the volume and a dense cement matrix consisting mainly of solid weakly crystallized high-basic calcium hydrosilicates with a ratio of $\mathrm{CaO} / \mathrm{SiO}_{2}=1.88(\mathrm{CSH}$ (II)) with inclusions of crystallized low-strength needle-type calcium hydrosilicates. Crystals of portlandite are also noted. Destruction occurs mainly through the contact zone "ceramic microsphere - cement matrix" and through the cement matrix. It was noted that the surface of the microspheres is covered with a layer of new phases with a thickness of not more than $1 \mu \mathrm{m}$, which indicates the physicochemical interaction of highly basic calcium hydrosilicates with a ceramic microsphere.

X-ray phase analysis of masonry mortar samples were carried out to identify new growths of cement stone with antifreeze additives. Figure 3 presents X-ray diagram of the lightweight masonry mortar with a HCMS, AEA, RPP and a complex of SN+SS. Besides the peaks which are ordinary for cement systems with hollow ceramic microspheres, calcium hydronitritaluminate of composition $3 \mathrm{CaO} \cdot \mathrm{Al}_{2} \mathrm{O}_{3} \cdot \mathrm{Ca}\left(\mathrm{NO}_{2}\right)_{2} \cdot 10 \mathrm{H}_{2} \mathrm{O}$ is also identified by peaks with $\mathrm{d}=(8,60 ; 7,90 ; 3,81) \cdot 10^{-10} \mathrm{~m}$. It should be noted a some decrease in the amount of portlandite (by the peak $\mathrm{d}=2,63 \cdot 10^{-10} \mathrm{~m}$ ) (about $15 \%$ ). The degree of hydration for this composition is slightly lower than that of the reference sample and is $65 \%$. There is an increase in the amount of ettringite (by peaks $d=(9,73 ; 5,61) \cdot 10^{-10} \mathrm{~m}$ ) by $30 \%$ compared with the reference sample, which, apparently, provides the high strength of the stone with the addition of sodium nitrite and sodium sulfate.

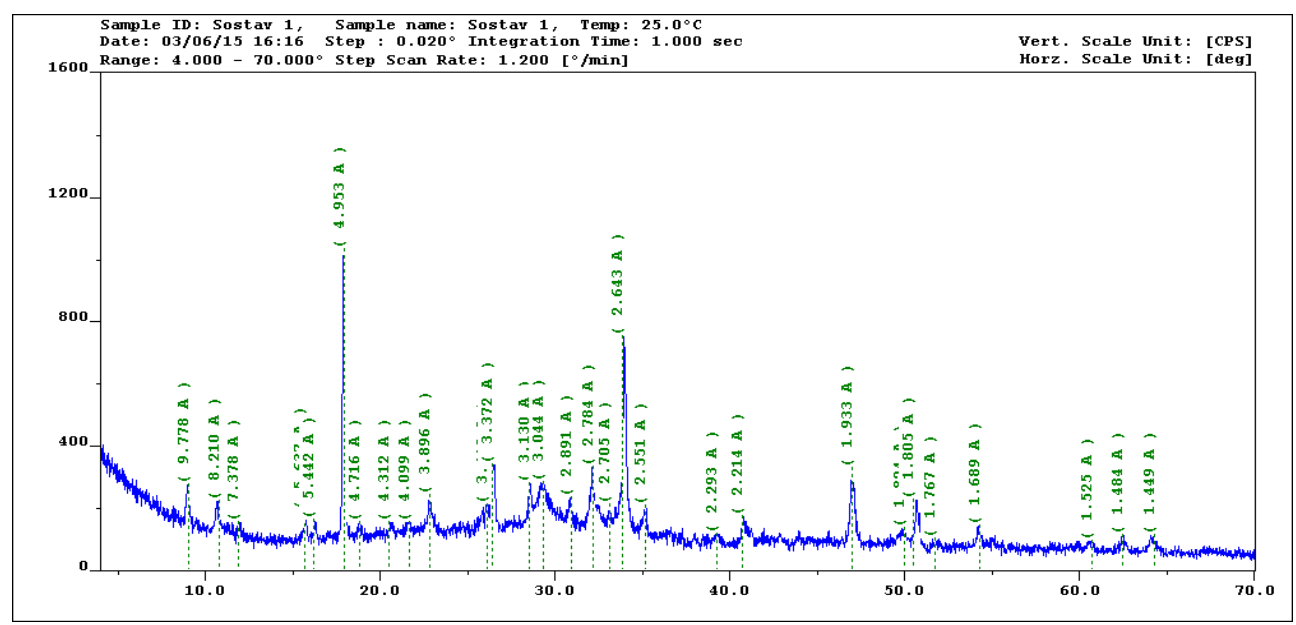

Fig. 4. X-ray diagram of a lightweight masonry mortar with hollow ceramic microspheres, airentraining additive, redispersible polymer powder, sodium formate and water repellent.

X-ray analysis of a lightweight masonry mortar with a HCMS, AEA, RPP and SF, presented in Figure 4, allows us to conclude that the amount of portlandite bound to calcite is somewhat lower compared with the control composition. On the X-ray diagram of the sample with SF, an increase in the intensity of calcium trihydrosulfoaluminate peaks was observed $\left(\mathrm{d}=(9,77 ; 3,88 ; 3,59 ; 3,24 ; 2,56) \cdot 10^{-10} \mathrm{~m}\right)$. The degree of hydration is $62 \%$.

On the X-ray diagram of the lightweight masonry mortar with HCMS, AEA, RPP and P (Figure 5), besides the peaks which are ordinary for cement systems with hollow ceramic microspheres, the following new phases can be identified: a large amount of calcite with $\mathrm{d}=(3,029 ; 2,277 ; 2,088 ; 1,912 ; 1,869 ; 1,52 ; 1,044) \cdot 10^{-10} \mathrm{~m}$; calcium hydrocarbonaluminate of composition $3 \mathrm{CaO} \cdot \mathrm{Al}_{2} \mathrm{O}_{3} \cdot \mathrm{CaCO}_{3} \cdot(11-12) \mathrm{H}_{2} \mathrm{O}$ with $\mathrm{d}=(7,6 ; 3,80 ; 2,86 ; 1,86) \cdot 10^{-1} \mathrm{~m}$; calcium hydroaluminates of the composition $4 \mathrm{CaO} \cdot \mathrm{Al}_{2} \mathrm{O}_{3} \cdot 13 \mathrm{H}_{2} \mathrm{O}$ can be contained - by the peaks with $\mathrm{d}=(8,2 ; 2,88 ; 2,86 ; 1,66 ; 1,65) \cdot 10^{-10} \mathrm{~m}$ and calcium hydroaluminates of the 
composition $2 \mathrm{CaO} \cdot \mathrm{Al}_{2} \mathrm{O}_{3} \cdot 8 \mathrm{H}_{2} \mathrm{O}-$ by the peaks with $\mathrm{d}=(10,7 ; 5,36 ; 2,87 ; 2,68 ; 2,55) \cdot 10^{-10}$ $\mathrm{m}$. The degree of hydration is $55 \%$, which is significantly lower than the degree of hydration of the reference sample.

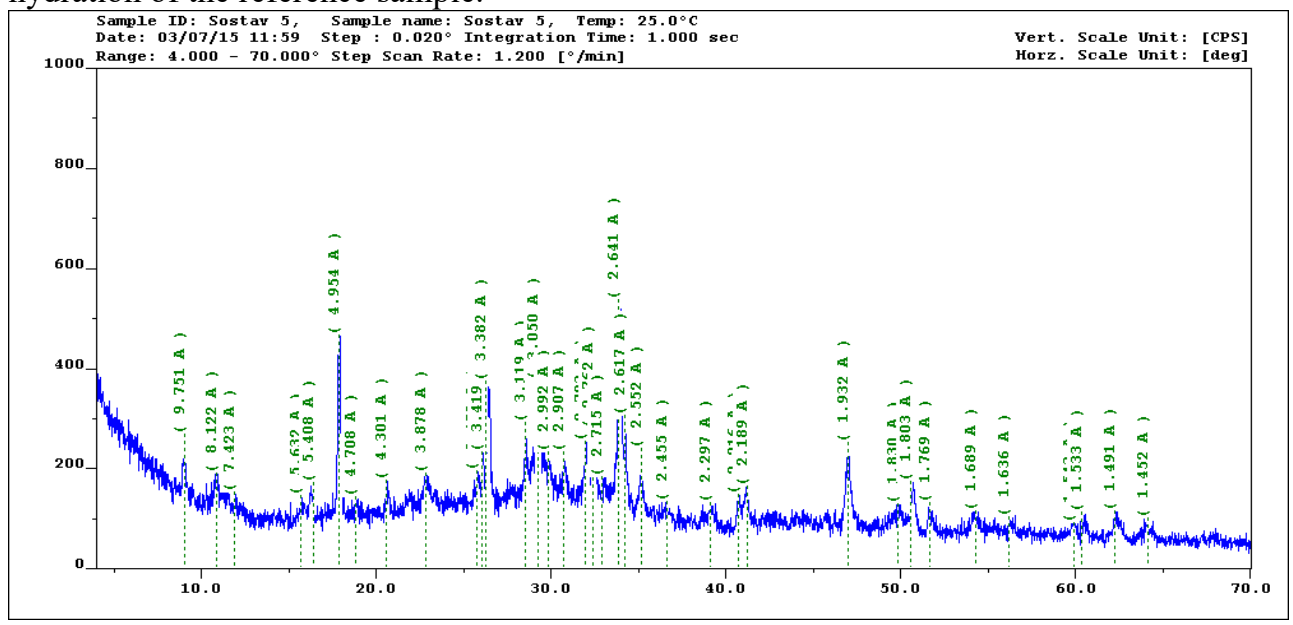

Fig. 5. X-ray diagram of a lightweight masonry mortar with hollow ceramic microspheres, airentraining additive, redispersible polymer powder, potassium carbonate and water repellent.

\section{Conclusions}

As a result of this research, the types of antifreeze additives and their optimal consumption for the modified lightweight dry mixes with hollow ceramic microspheres, an air-entraining additive, and a redispersible polymer powder were determined. These modifiers provide a mortar with a set of minimum required strength at temperatures of $-10 \ldots+5^{\circ} \mathrm{C}$ while ensuring the required technological properties of mortar mixtures. It has been shown that the most effective of the additives considered is potassium carbonate, which provides hardening at negative temperature for compressive and tensile bending strength not less than $60 \%$ of the strength of the reference sample hardened at a positive temperature. It is advisable to use potassium carbonate together with a setting retarder. Sodium formate and sodium nitrite in combination with sodium sulfate have approximately the same effect, providing compressive and tensile bending strength of at least $40 \%$ of the strength of the reference sample. The introduction of the water repellent into the lightweight dry masonry mixture with antifreeze additives allows to significantly reduce the salt formation on the surface of the mortar and to reduce water absorption. The mortars of all compositions are water resistant (water resistance coefficient over 0.8), and the frost resistance of compositions with water repellent corresponds to the reference sample or exceeds it. The achieved characteristics of the lightweight dry masonry mixtures correspond with the results of microstructural and X-ray analysis of masonry mortar samples.

\section{References}

1. D. Oreshkin, V. Semenov, T. Rozovskaya, Pr. Eng., 153, 638 (2016)

2. V. Semenov, T. Rozovskaya, IOP Conf. Ser.: Mat. Sc. and Eng., 71(1), 012042 (2015)

3. V. Semenov, T. Rozovskaya, Pr. Eng., 153, 623 (2016)

4. R. Demirboğa, İ. Örüng, R Gül, Cem. and Concr. Res., 31 (11), 1627 (2001)

5. Z. Li, Z. Su, L. Li, H. Mi, W. Meng, Y. Huang, J. Yang, J. of the Ch. Cer. Soc., 45(3), 384 (2017). 
6. A. Inozemtcev, E. Korolev, Key Eng. Mat., 743, 68 (2017)

7. I. Bessonov, O. Larsen, L. Alimov, V. Voronin, A. Sapelin, N. Komorova, IOP Conf. Ser.: Mat. Sc. and Eng., 365(3), 032011 (2018)

8. Z. Huang, F. Wang, Y. Zhou, L. Sui, P. Krishnan, J.Y.R. Liew, Mat., 11(10), 2043 (2018)

9. Z. Huang, K. Padmaja, S. Li, J.Y.R. Liew, Constr. and Build. Mat., 164, 760 (2018)

10. D. Khodzhaev, B. Normuminov, Y. Mustapakulov, A.Mottaeva, E3S Web of Conferences, 110, 01045, (2019) doi.org/10.1051/e3sconf/201911001045

11. P. Chen, J. Wang, F. Liu, X. Qian, Y. Xu, J. Li, Constr. and Build. Mat., 159, 431 (2018)

12. A. Brooks, H. Zhou, D. Hanna, Constr. and Build. Mat., 159, 316 (2018)

13. V. Rheinheimer, Y. Wu, T. Wu, K. Celik, J. Wang, L. De Lorenzis, P. Wriggers, M.-H. Zhang, P.J.M. Monteiro, Cem. and Concr. Comp., 80, 91 (2017)

14. A. Hanif, Z. Lu, S. Diao, X. Zeng, Z. Li, Constr. and Build. Mat., 140, 139 (2017)

15. V. Semenov, MATEC Web of Conf., 117, 00149 (2018)

16. V. Semenov, MATEC Web of Conf., 251, 01045 (2018)

17. V. Smirnov, T. Rozovskaya, V. Semenov, Sc. Rev., 10-2, 78 (2015) 